УДК 94(477):341.71

\title{
Олена Спицька
}

науковий співробітник відділу

«Музей Украӥнської революиії 1917-1921 років» Національного

музею історії Украӥни

\section{АДМІНІСТРАТИВНО-ФІНАНСОВА ДІЯЛЬНІСТЬ КЕРІВНИЦТВА УКРАЇНСЬКОЇ ДЕЛЕГАЦІЇ НА ПАРИЗЬКІЙ МИРНІЙ КОНФЕРЕНЦІЇ 1919-1920 РР. КРІЗЬ ПРИЗМУ НОВОГО ІСТОРИЧНОГО ДЖЕРЕЛА}

Публікація висвітлює деякі організаційні заходи щуодо кадрового $і$ фінансового забезпечення діяльності делегащії УНР на Паризькій мирній конферениіі 1919-1920 рр. з метою добитися визнання незалежності УНР провідними та іншими державами світу, врахування інтересів украӥнського народу у ході повоєнних геополітичних змін у Центральній i Східній Свропі, налагодження політичної, військової та торговельно-економічної співпраці з іншими країнами. Характеризує головні напрями кадрової складової изієі діяльності - динаміку у кадрових змінах, намагання залучити до роботи кваліфікованих фахівців і технічних працівників, ведення контролю за відрядженням членів делегації; фінансові заходи, спрямовані на виконання завдань, щуо стояли перед делегацією. Ключові слова: УНР, Париж, делегачія, наказ.

1 (2017). Документи про участь об'єднаної делегації УНР та ЗУНР у Паризькій мирній конференції 1919-1920 рр. У Спеціальні історичні дисципліни: питання теорії і методики. Збірка наукових праць. Число 28. К.: НАН України, Інститут історії України, С. 229-288.

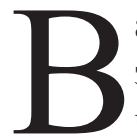

ажливим і неоднозначним епізодом в історії визвольних змагань Українського народу наприкінці другого десятиріччя ХХ століття була участь об’єднаної делегації Української Народної Республіки та Західноукраїнської Народної Республіки у Паризькій мирній конференції 1919-1920рр. (офіційна назва делегації - «Делегація об'єднаної УНР на мирову конференцію в Парижі»). Попри велике значення цієї сторінки в історії української дипломатії, для об'єктивної оцінки діяльності делегації досі не вистачає надійних документальних джерел. 3 метою частково компенсувати наявні прогалини у відомій дослідникам джерельній базі авторкою у 2017 р. було підготовлено науково-документальну публікацію «Документи про участь об'єднаної делегації УНР та ЗУНР у Паризькій мирній конференції 1919-1920 рр.»1, в якій було представлено дев'ять протоколів засідань делегації (докладніше про це див. далі).

Матеріал, що пропонується увазі читачів, є тематичним продовженням тієї публікації, тому при підготовці його електронної версії частково використано вступну (історичну) частину до попередньої $з$ додаванням сюжету про нове історичне джерело - Книгу наказів по Делегації. Ця Книга оприлюднюється вперше і у поєд- 
нанні з опублікованими протоколами засідань делегації є цінним історичним джерелом для вивчення умов іiі діяльності.

Паризька мирна конференція, що тривала від 18 січня 1919 р. до 21 січня 1920 р., була міжнародним форумом держав-переможниць у Першій світовій війні 1914-1918 рр. Під час конференції було розроблено п'ять мирних договорів із країнами Четвертного союзу (Німеччиною, Австрією, Угорщиною, Болгарією, Туреччиною), що зазнали поразки у війні. Ці договори, підписання яких розтягнулося у часі, заклали фундамент Версальської системи міжнародних відносин. 28 червня 1919 р. був підписаний Версальський мирний договір між країнами Антанти та Німеччиною. В інших договорах були зафіксовані державні кордони, що виникли внаслідок розвалу колишніх багатонаціональних імперій (Австро-Угорської, Османської та Російської) і утворення нових національних держав у Центрально-Східній Європі. За Сен-Жерменським мирним договором з Австрією від 10 вересня 1919 р. припинила існування Австро-Угорська монархія. 27 листопада 1919 р. був підписаний Нейїський мирний договір із Болгарією, 4 червня 1920 p. - Тріанонський мирний договір з Угорщиною, а 10 серпня 1920 р. - Севрський договір з Туреччиною, за яким відбувався поділ колишньої Османської імперії. Важливим підсумком конференції стало утворення незалежної Польщі, однак ії̈ кордони охоплювали частину німецьких, чеських і українських земель, що спричинило в майбутньому гострі міжнародні суперечності.

Головну роль у процесі прийняття рішень відігравала Рада трьох (прем'єр-міністр Великої Британії Д. Ллойд-Джордж, прем'єр-міністр Франції Ж. Клемансо і президент США Т. В. Вільсон). До керівних органів Паризької мирної конференції належали Рада чотирьох (у складі названих діячів та прем'єр-міністра Італії В. Е. Орландо), Рада п’яти (членами якої були міністри закордонних справ Великої Британії, Франції, США, Італії, а також колишній прем'єр-міністр Японії С. Кіммоті) і Рада десяти (до іiі складу входили по два представники від кожної з названих вище держав). Інші союзники Антанти у деяких випадках викладали в меморандумах на адресу керівних органів власну позицію або на пленарних засіданнях погоджувалися із сепаратно виробленими рішеннями великих держав.

Під час тривалих дебатів та обговорення мирних договорів із переможеними країнами (на конференції було утворено 52 комісії $з$ підготовки умов договорів з окремих проблем) виникли серйозні протиріччя між основними учасниками переговорів, проте в більшості випадків було досягнуто компромісів. Підготовка договорів формально відбувалася на основі «14 пунктів президента Вільсона», тобто при визначенні кордонів повоєнної Свропи потрібно було виходити з принципу національності й самовизначення, а головною умовою повоєнного устрою мало стати створення більш справедливого і демократичного порядку, який би виключав повторення світової війни і забезпечив мир через роззброєння та заснування Ліги Націй як інструменту миру. 28 квітня 1919 р. був затверджений Статут Ліги Націй, який увійшов як складова частина до всіх мирних договорів. 
На конференцію було запрошено делегації з 27 країн, з яких 10 брали безпосередню участь у війні, 14 формально знаходились у стані війни, а також три новостворені держави (Польща, Чехо-Словаччина, Королівство Сербів, Хорватів і Словенців). Радянську Росію та національні державні утворення, що виникли на теренах колишньої Російської імперії, у тому числі УНР, до участі в роботі конференції не було запрошено.

Щоб отримати офіційне запрошення на конференцію, аби відстояти національні інтереси і державність українців, уряди УНР та ЗУНР доклали значних зусиль, проте їх звернення залишилися поза увагою організаторів. За цих умов, 29 грудня 1918 р. Рада Народних Міністрів УНР на чолі з В. Чехівським прийняла рішення про відправку на конференцію делегації УНР, яке офіційно було затверджене 10 січня 1919 р. спеціальним законом. До складу делегації, загальна чисельність якої становила понад 75 осіб, входили: Г. Сидоренко (голова), А. Петрушевич (перший секретар), П. Дідушок (секретар), Б. Матюшенко, О. Севрюк, О. Шульгін, А. Марголін, М. Кушнір, Д. Ісаєвич та інші. Заступником голови делегації був державний секретар закордонних справ ЗУНР (з 22 січня 1919 р. - Західної області УНР) В. Панейко. До складу делегації ЗУНР увійшли також С. Томашівський, М. Лозинський, М. Рудницький, О. Кульчицький та державний секретар військових справ ЗУНР полковник Д. Вітовський. До об'єднаної делегації приєдналася також делегація українців із Північної Америки О. Мегас та I. Петрушевич.

20 січня 1919 р., тобто вже після початку роботи конференції, до Парижу змогли дістатися тільки голова делегації Г. Сидоренко та іiі перший секретар А. Петрушевич, а решта посланців прибули значно пізніше. Пояснюється це тим, що французький уряд досить довго не давав дозволу на в’їзд, і тому представники УНР змушені були зупинитися у Швейцарії, де провели кілька попередніх нарад. 3 огляду на це, а також те, що українська делегація так і не була визнана і могла розраховувати лише на неофіційні зустрічі 3 іншими делегаціями, обговорення на конференції наслідків розпаду Російської імперії та Австро-Угорщини відбувалося без урахування українських інтересів. Посилання українських дипломатів на тези президента США В. Вільсона про право націй на самовизначення не знаходили розуміння.

Політика щодо України формувалася на основі підтримки країнами Антанти польської сторони під час польсько-українського конфлікту 1918-1919 рр., а також надання допомоги російським білогвардійським арміям А. Денікіна та П. Врангеля. Представники діаспори О. Мегас та I. Петрушевич мали контакти 3 прем'єр-міністром Канади Р. Боденом, а через нього - й з британським прем'єром. Завдяки цьому В. Вільсон і Д. Ллойд-Джорж не завжди підтримували позицію Ж. Клемансо стосовно зазіхань Польщі на землі Східної Галичини. Однак, 25 червня 1919 р. лідери великих країн ухвалили рішення про дозвіл польським військам окупувати Східну Галичину до річки Збруч, що означало повну ліквідацію державного існування ЗУНР (3О УНР) та введення цивільної адміністрації на цій території. Внаслідок утвер- 
дження у Свропі повоєнної Версальської системи міжнародних відносин, українські землі були розділені між чотирма державами: Наддніпрянська Україна була окупована більшовиками та включена до складу утвореного в 1922 р. Радянського Союзу; Галичина та Західна Волинь опинилися у складі Польщі; Північна Буковина та Південна Бессарабія стали частинами Румунії, а Закарпаття увійшло до складу Чехословаччини.

Українська делегація представників УНР та ЗУНР, яка працювала на цій конференції, стала найважливішим українським представництвом закордоном у 1919-1920 рр. Делегація отримала інструкції домагатися визнання незалежності УНР, виводу з української території іноземних військ, надання допомоги Антантою в боротьбі проти більшовиків Росії та Добровольчої армії генерала А. Денікіна. Крім цього, навесні 1919 року до Парижа прибула спеціальна делегація на чолі з Д. Вітовським та М. Лозинським, яка за дорученням Державного Секретаріату 30 УНР мала домагатися припинення агресії Польщі проти $3 О$ УНР. Проте, позицію українців ускладнювали не тільки несприятливі об'єктивні фактори, але й суб'єктивні: зворотнім боком великої кількості членів делегації була розбіжність поглядів її учасників, зокрема, тому, що деякі з них вважали себе передусім представниками певного регіону чи групи.

Важливим історичним джерелом для вивчення цієї «внутрішньої кухні» діяльності делегації є протоколи її засідань під час Паризької мирної конференції, а також Книга наказів, яка велася весь час перебування Делегації в Парижі, а саме упродовж 20 січня 1919 року - 16 серпня 1920 року. У Державному архіві Російської Федерації зберігається низка фондів державних інституцій УНР, зокрема, «Дипломатична місія УНР в Парижі» (Р-6275) та «Делегація УНР на Мирній конференції в Парижі» (Р-7027). Проте, в опублікованих документальних збірках, у тому числі й тій, де міститься наведена інформація, жоден протокол засідання української делегації не представлений. Відсутні також будь-які згадки про існування Книги наказів Делегації.

Водночас у Києві, у бібліотеці ім. О. Ольжича, окрім дев'яти протоколів за період 4-24 червня 1919 р., зберігається ще й рукопис Книги наказів Української делегації на Паризькій мирній конференції. Фізичний стан цього історичного документу є у цілому критичним. Значну частину тексту у первинному вигляді, що написаний синім чорнилом, майже втрачено. Судячи з усього, на документ потрапила вода, i тому поверх розмитого тексту слова и літери відтворено шляхом наведення олівцем або чорнилом чорного кольору. Проте, стан документу дозволяє навіть візуально визначити автентичність первинного й відтвореного текстів.

Загальний обсяг Книги наказів становить 48 рукописних сторінок розміром 29,5 х 19,5 см. Текст двосторонній. Сторінки не пронумеровані. Книга містить 95 наказів щодо роботи делегації. Вели Книгу різні люди. Наказ № 1 був написаний самим Г. Сидоренком, який прибув до Парижа і приступив до виконання службових обов'язків Президента делегації УНР в Парижі. Наказом № 2, який також датується 20 січня 1919 року, був призначений секретар делегації А. Петрушевич. 
За час роботи конференції і ведення Книги наказів (з 20 січня 1919 р. до 16 серпня 1920 р.) змінилося троє секретарів делегації, а саме: А. Петрушевич, П. Дідушок, М. Рудницький. Останній наказ по делегації за № 95 від 16 серпня 1920 р. був підписаний по уповноваженню Колєгії, що була створена Наказом Високої Директорії з 20 липня 1920 р. Колєгія передала тимчасове керування справами Делегації М. Лучинському, який і підписав цей наказ.

Накази мають певні відмінності у формі їхнього написання. Відрізняються також правопис та стилістика, що пов'язане $з$ індивідуальними особливостями осіб, які вели Книгу наказів.

Інформаційний потенціал Книги наказів як історичного джерела є досить важливим. Він, наприклад, дозволяє скласти уявлення про організаційно-штатну побудову Української делегації аж до технічних працівників. I хоча назви посад виглядають цілком звичайними, функції, що виконували особи, які їх обіймали, були вкрай важливими для ефективної роботи делегації. Як видно 3 Книги наказів, у штаті делегації були передбачені посади трьох перекладачів, чотирьох машиністок, двох писарок, двох швейцарів та одного посильного. Про більшість 3 цих людей не вдалося знайти жодної інформації.

Книга наказів $є$ також цінним джерелом інформації щодо фінансового забезпечення діяльності Української делегації. 3 опублікованих документів відомо, що 10 січня 1919 р. Рада Народних Міністрів УНР ухвалила Закон Директорії УНР про надіслання

2 Див.: Андрієвська, Л.В. (ред.). (2010). Історія української дипломатії: перші кроки на міжнародній арені (19171924 рр.): документи і матеріали. К.: Вид-во гуманіт. л-ри, C. 293-295.

${ }^{3}$ Храпко, I. (1919). Збірник законів і постанов Українського Правительства відносно закордонних інструкцій. Ч. 1. Відень, С. 79-80.
Надзвичайної дипломатичної місії УНР до Франції, штати місії та асигнування коштів на їі утримання у розмірі 3228340 карбованців упродовж трьох місяців. У перерахунку за тодішнім курсом валют - 1 французький франк дорівнював 1 рублю (так у документі) 55 копійкам - це становило 2082800 франків². А 24 січня 1919 р. був прийнятий ще один Закон про асигнування на утримання Надзвичайної Дипломатичної місії до Франції упродовж одного місяця 958830 карбованців ${ }^{3}$.

Книга наказів дозволяє конкретизувати питання про розподіл цих коштів у частині використання фонду заробітної плати працівників делегації. Згідно із Книгою наказів найвищу платню отримували радники делегації - 5000 франків, найнижчу - машиністки та писарки, але з часом їхня платня збільшилася від 200 до 400 франків на місяць. Аташе отримували 4000 франків, секретарі делегації - від 3000 до 4000 франків, перекладачі отримували від 800 франків на початку роботи делегації до 2000 франків наприкінці їі роботи.

Підвищення зарплатні відбулося після того, як делегацію очолив 22 серпня 1919 р. граф М. Тишкевич. За час головування М. Тишкевича в складі делегації відбулося дві ротації кадрів. Після того як 6 вересня Г. Сидоренко виїхав в Україну, а зі складу делегації вийшли О. Шульгин та А. Марголін, в штаті було введено нові посади, як то посада особистого прибічника (помічника), помічного прибічника, експерта 3 фінансових питань на посаді урядовця делегації. 3'являються і нові обличчя у складі делегації - В. Моцарський, Б. Цитович, Ф. Мазад, барон Гроот, Л. Галяфре, I. Борщак. 
${ }^{4}$ Себта, Т. (2017). Нові факти про визнання у 1921 р. Республікою Аргентини Української Народної Республіки. Зовнішні справи. № 12. С. 27.
16 грудня 1919 р. зі складу делегації вийшли представники ЗУНР В. Панейко, С. Томашівський, А. Петрушевич, О. Кульчицький, М. Лозинський. А вже 30 грудня, згідно з одержаною телеграмою від Уряду УНР від 18 грудня, було оголошено про ліквідацію делегації у старому складі та формування нового складу делегації.

На думку сучасних дослідників історії української дипломатії, час та обставини ліквідації Надзвичайної Дипломатичної Місії УНР у Франції в історичній літературі є маловивченими. Відомо, що Надзвичайна Дипломатична місія УНР у Франції діяла найдовше - до початку 1930-х рр., але називалася вже просто - Місія УНР у Парижі. При цьому треба зазначити, що місія у першій половині 1920-х рр. переживала сильну фінансову скруту, можливо, навіть деякий час не працювала. У другій половині серпня 1921 p. голова місії О. Шульгин через брак коштів планував звільнити іiі співробітників, а у вересні 1921 р. закрити місію. У листі до Симона Петлюри від 11 серпня 1921 р. 3 приводу цього він болісно наголошував на наслідках ліквідації місії: «Закриття ж місії в Парижі - це смерть УНР на міжнародному полі!!». I прохав терміново вислати кошти ${ }^{4}$. Нажаль, поки що достеменно не відомо, як було вирішене це питання.

Книга наказів надає доволі унікальну інформацію про поточний перебіг роботи української делегації. Ї̈і введення до широкого обігу та уважне вивчення змісту наказів фахівцями безумовно сприятиме формуванню більш цілісної та об'єктивної характеристики діяльності української делегації під час Паризької мирної конференції, а також оцінки результатів цієї діяльності у широкому історичному контексті.

Документ подано з максимальним збереженням мови оригіналу та мінімальними правками наявних граматичних помилок. На жаль, не всі сторінки читабельні, а в окремих випадках передати ïх неможливо. У примітках наведено пояснення щодо окремих іншомовних слів.

У Книзі згадується багато відомих представників Українського визвольного руху, які продовжували відігравати важливу роль у ньому і в подальшому. Проте чимало осіб були лише випадковими учасниками у роботі делегації. Книга наказів у сукупності 3 протоколами засідань делегації та іншими джерелами інформації допомагає зрозуміти реальний внесок кожної особи - від керівників делегації до технічних працівників - у результати діяльності Української делегації на Паризькій мирній конференції. Це $\epsilon$ необхідною умовою для наукового аналізу взаємодії об'єктивних i суб'єктивних факторів, що впливали на діяльність делегації і врешті визначили іiі місце в історії визвольних змагань Українського народу. 
${ }^{5}$ Назва написана від руки чорнилами на окремому аркуші.

${ }^{6}$ Сидоренко Григорій Микитович (1847-1924) - український політичний діяч і дипломат, інженер шляхів. Міністр пошт і телеграфу УНР. Голова делегації УНР на Паризькій мирній конференції. У серпні 1919 р. Директорія УНР замінила його на цій посаді М. Тишкевичем.

${ }^{7}$ Петрушевич Антін (Антон) Євгенович (1892 - ймовірно 1941) - син С. Петрушевича, активний учасник зовнішньополітичної діяльності ЗУНР, член української делегації на Паризькій мирній конференції 1919-1920 pp.

${ }^{8}$ Савченко Федір Якович (1892 - після 1937) - український історик, літературознавець, публіцист. У 1918 p. заснував французько-українське товариство Cerele d'etudes franco-ukrainiennes, редактор тижневика «La France et l'Ukraine». За допомогою М. Грушевського повернувся в Україну у 1925 р. У 1931 р. заарештований ДПУ УСРР у справі «Українського Національного Центру» і засланий. У 1937 р. заарештований вдруге. Від липня 1938 року від нього не було звісток вірогідно страчений або помер в ув'язненні.

${ }^{9}$ «Bureu Ukraïnien de presse» (фр.) - українське бюро преси.

\section{Книга наказів ${ }^{5}$}

\section{Наказ № 1}

20 січня 1919 p.

Прибув 20. Січня 1919 р. до Парижа і приступив до виконування обов[']язків Президента делєгації Української Народної Республіки в Парижі.

Президент делєгації У.Н.Р. в Парижі: Г. Сидоренко ${ }^{6}$

\section{Наказ № 2}

20 січня 1919 року

Призначаю п. Петрушевича Антона ${ }^{7}$ секретарем делєгації Української Народної Республіки в Парижі з місячним окладом в 3000 (три тисячі) французьких франків з 20 січня 1919 року.

Президент делєгації Української Народної Республіки: Г. Сидоренко

Секретар: Антін Петрушевич

\section{Наказ № 3}

1 лютого 1919 року

Призначається Голова Національної Української Ради у Франції п. Савченко Федір 8 для праці в делєгації Української Народної Республіки з місячним окладом 2.000 (дві тисячі) франків 31 лютого 1919 р. $з$ дорученням йому організувати «Bureu Ukraïnien de presse» ${ }^{9}$.

Президент делєгації Української Народної Республіки: Г. Сидоренко

Секретар: Антін Петрушевич

\section{Наказ № 4}

7 лютого 1919 року

Секретарю делєгації п. Петрушевичу Антону наказую негайно виїхати до Швейцарії для полагодження справ делєгації.

Президент делєгації Української Народної Республіки в Парижі: Г. Сидоренко

Секретар: Антін Петрушевич

\section{Наказ № 5}

14 лютого 1919 року

Секретар делєгації п. Антін Петрушевич 14. дня лютого повернувся з Швейцарії і приступив до виконування своїх службових обов[']язків.

Президент делєгації Української Народної Республіки: Г. Сидоренко

Секретар: Антін Петрушевич 
${ }^{10}$ Мегас Осип (1884-1955) громадський діяч у Канаді, куди прибув 1905 р. з Галичини; 1906 редактор «Канадійського Фармера», 1919 делегат Українського Горожанського Комітету в Канаді на мирову конференцію в Парижі, з 1926 лікар в Едмонтоні, автор книги «Трагедія Галицької України».

${ }^{11}$ Петрушевич Іван (18751959) - український письменник, сценарист, перекладач, громадсько-культурний діяч української діаспори в Канаді і США. Псевдонім (Е.Van Pedroe-Savidge). Співпрацював 3 українськими дипломатичними місіями УНР, був секретарем дипломатичного представництва ЗУНР у Лондоні (1920-1923).

12 Дідушок Петро Федорович (1889-1937) - український громадський і політичний діяч, дипломат, член УСДРП, секретар української делегації на Паризькій мирній конференції 1919-1920 pp.

13 Зархій (Зархі) Сергій - працівник посольства УНР в Лондоні.

${ }^{14}$ Шульгин Олександр Якович (1889-1960) - український громадський, політичний i державний діяч, історик, публіцист, член ТУП, а потім УПСФ. У 1917 р. - член Української Центральної Ради, генеральний секретар міжнародних справ. У 1918 р. - посол УНР в Болгарії. У 1919 р. - член делегації УНР на Паризькій мирній конференції. Голова україн-

\section{Наказ № 6}

12 марта 1919 року

Прибувший з Лондона до Парижа член делєгації українців 3 Канади п. Мегас Осип ${ }^{10}$ призначається для праці в делєгації Української Народної Республіки в Парижі.

Президент делєгації Української Народної Республіки: Г. Сидоренко

Секретар: Антін Петрушевич

\section{Наказ № 7}

14 марта 1919 року

Прибувший з Лондона до Парижа член делєгації від українців з Канади п. Петрушевич Іван ${ }^{11}$ призначається для праці в делєгації Української Народної Республіки в Парижі.

Президент делєгації Української Народної Республіки: Г. Сидоренко

Секретар: Антін Петрушевич

\section{Наказ № 8}

18 марта 1919 року

Прибули з Швейцарії до Парижа 18 дня марта 1919 року секретар делєгації Української Народної Республіки в Парижі п. Петро Дідушок ${ }^{12}$ і член політичної секції делєгації іiї др. Сергій Зархі ${ }^{13}$ і приступили до виконування своїх обов[']язків. П. Петрушевич Антін призначається другим секретарем делєгації.

Президент делєгації Української Народної Республіки: Г. Сидоренко

Секретарь: Петро Дідушок

\section{Наказ № 9}

20 марта 1919 року

Прибули з Швейцарії до Парижу 20. марта 1919 р. п.п. Шульгин Олександр ${ }^{14}$, член дипломатичної секції делєгації Укр[аїнської] Нар[одної] Респ[убліки] в Парижі, Шелухин Сергій ${ }^{15}$, радник делєгації, і Дмитро Ісаєвич ${ }^{16}$, член політичної секції делєгації, і приступили до виконування своїх обов[']язків.

Президент делєгації Укр[аїнської] Нар[одної] Респ[убліки]: Г. Сидоренко

Секретарь: Петро Дідушок

ської делегації на першій асамблеї Ліги Націй у Женеві. 31921 р. очолював Надзвичайну дипломатичну місію УНР у Парижі. 3 1920-х років - в еміграції. Брав участь у емігрантських урядах УНР.

${ }^{15}$ Шелухин Сергій Павлович (1864-1938) - український громадський, політичний і державний діяч, правознавець, історик. У 1919 р. - радник української делегації на Паризькій мирній конференції.

${ }^{16}$ Ісаєвич Дмитро Григорович (1889-1973) - український громадський, політичний

і державний діяч, журналіст.

3 січня 1919 р. - економічний радник української делегації на Паризькій мирній конференції 1919-1920 рр. 
17 Панейко Василь Лукич (1883-1956) - український громадський і політичний діяч, дипломат, публіцист, член УНДП. У 1919 р. - заступник голови, з грудня 1919 - голова делегації ЗУНР на Паризькій мирній конференції 19191920 pp.

${ }^{18}$ Матюшенко Борис Павлович (1883-1944) - український громадський, політичний i державний діяч, лікар, гігієніст, доктор медицини (1912), професор. Входив до складу української делегації на Паризькій мирній конференції 1919-1920 pp.

19 Тимошенко Володимир Прокопович (1885-1965) український економіст (зокрема із сільського господарства), дійсний член НТШ й УВАН. У 1919 р. - економічний радник української дипломатичної місії на Паризькій мирній конференції.

${ }^{20}$ Колосовський Володимир Васильович (1884-1944) український військовий діяч. Після проголошення Української держави на чолі з Гетьманом Павлом Скоропадським і реорганізації у червні 1918 р. Генерального штабу Збройних сил України був призначений начальником розвідочного відділу. 312 січня 1919 р. військовий експерт делегації УНР на Паризькій мирній конференції 1919-1920 рр.

${ }^{21}$ Рудницький Михайло Іванович (1889-1975) - український літературний критик, літературознавець, письменник, поет, перекладач. Дійсний член НТШ, доктор філософії (1914 р.). Від 29 березня 1919 р. працював секретарем дипломатичної місії УНР в Парижі.

22 attaché a là delegation (фp.) аташе делегації.

\section{Наказ № 10}

22 марта 1919 року

Прибули з Швейцарії до Парижу 22. марта 1919 п.п. др. Василь Панейко ${ }^{17}$, віце-президент делєгації , др. Борис Матюшенко $^{18}$, член політичної секції делєгації, i Тимошенко Володимир ${ }^{19}$, радник фаховець делєгації, і приступили до виконування своїх обов[']язків.

Президент делєгації Україн[ської] Народн[ої] Республіки: Г. Сидоренко

Секретарь: Петро Дідушок

\section{Наказ № 11}

23 марта 1919 року

Прибули з Швейцарії до Парижу 23. марта с.р. полковник Колосовський Володимир ${ }^{20}$ радник фаховець делєгації, i др. Михайло Рудницький ${ }^{21}$, викликаний мною на посаду третього секретаря делєгації і приступили до виконування своїх обов[']язків.

Президент делєгації Української Народної Республіки: Г. Сидоренко

Секретарь: Петро Дідушок

\section{Наказ № 12}

24 марта 1919 року

Призначається п[ан]на Перільо Олена машиністкою 3 днем 20-ого лютого с.р. на оклад жалування 200.- франків в місяць.

Презідент делєгації Укр[аїнської] Нар[одної] Республіки:

Г. Сидоренко

Секретар: Антін Петрушевич

\section{Наказ № 13}

1 квітня 1919 року

Призначаються п.п. Петрушевич Іван, Мегас Осип і Савченко Федір attaché a là delegation ${ }^{22} 3$ днем 1.квітня c.p. 3 місячним окладом в 4.000 франків кожному.

Презідент делєгації Укр[аїнської] Нар[одної]Республіки: Г. Сидоренко

Секретарь: Петро Дідушок

\section{Наказ № 14}

2 квітня 1919 p.

Призначається Др. Рудницький Михайло третім секретарем делєгації Укр[аїнської] Нар[одної] Респ[убліки] в Парижі $з$ днем 1. квітня с.p. 3 місячним окладом в 3.000 франків.

Презідент Делєгації У[країнської] Н[ародної] Р[еспублікої] Г. Сидоренко

Секретарь: Петро Дідушок 


\section{Наказ № 15}

3 квітня 1919 p.

Призначаються: п. Чертопруд Пилип, швейцаром делєгації 31. квітня с.р. 3 місячним окладом 500. фр. , Чертопруд Анна, швейцарки делєгації з 1. квітня с.р. 3 місячним окладом 300 фр.

Презідент делєгації У[країнської] Н[ародної] Р[еспублікої]: Г. Сидоренко

Секретарь: Петро Дідушок

\section{Наказ № 16}

4 квітня 1919 p.

Призначаються п. Женевієва (Женев’єва) Іра машиністкою 3 днем 1. квітня с.p. на місячний оклад 200 франків.

Презідент делєгації У[країнської] Н[ародної] Р[еспублікої]:

Г. Сидоренко

Секретарь: Петро Дідушок

\section{Наказ № 17}

6 квітня 1919

Призначається п. Андре Фурніє машиністкою 3 днем 6. квітня c.p. 3 місячним окладом 350 фр.

Презідент делєгації У[країнської] Н[ародної] Р[еспублікої]: Г. Сидоренко

Секретарь: Петро Дідушок

\section{Наказ № 18}

з 10 квітня 1919 p.

Призначається п. Трільоф Фернанд посильним в делєгації 3 днем 10. квітня с.р. за місячним окладом 250.фр.

Презідент делєгації У[країнської] Н[ародної] Р[еспублікої]: Г. Сидоренко

Секретарь: Петро Дідушок

\section{Наказ № 19}

з 15 квітня 1919 .

Секретар делегації п. Антін Петрушевич виїхав сьогодні 3 мого поручення до Відня для полагодження справ делєгації.

Президент делегації: Г. Сидоренко

Секретар: Михайло Руднищький

\section{Наказ № 20}

24 квітня 1919 p.

Віце-президент делєгації др. Василь Панейко виїхав сьогодні до Швейцарії для полагодження справ делєгації.

Президент делєгації: Г. Сидоренко

Секретар: Михайло Рудницький 


\section{Наказ № 21}

26 квітня 1919 p.

Призначується п-на Аніся Rеy машиністкою з дня 17 квітня 1919 р. $з$ місячною платою 350 фр.

Президент делєгації: Г. Сидоренко

Секретар: Михайло Рудницький

\section{Наказ № 22}

27 квітня 1919 p.

Призначається п. Дібруа Шарль урядовцем делєгації (перекладчик) з днем 5. квітня 1919 р. за місячним окладом 800 фр[анків].

Презідент делєгації: Г.Сидоренко

Секретарь: Петро Дідушок

\section{Наказ № 23}

${ }^{23}$ Білик Кирило - американський громадський діяч (США); був надісланий від Українського Американського Комітету на допомогу українській делегації на Паризькій мирній конференції в 19191920 pp.

${ }^{24}$ Джеймс Гаміль (Гаміл, James Alphonsus Hamill) (18771941) - адвокат, член Генеральної Асамблеї Нью-Джерсі (1902-1905); представник демократичної партії в Конгресі США від штату Нью-Джерсі (1907-1921); в 1919-1920 pp. представник українців США на Паризькій мирній конференції; почесний кавалер Французького Легіону за заслуги у французькій літературі.

${ }_{25}$ Йдеться про конференцію Другого (Соціалістичного або Робочого) інтернаціоналу, що відбулася у квітні 1919 р. у м. Амстердам (Нідерланди).
29 квітня 1919 p.

Прибувши 7 квітня с.р. 3 Америки п. Др. Кирило Білик ${ }^{23}$ i сенатор Джеймс Гаміль ${ }^{24}$, уповноважені представники американських українців від з[']єднаних штатів призначаються для праці в делєгації Української Народної Республіки в Парижі.

Презідент делєгації: Г. Сидоренко

Секретарь: Петро Дідушок

\section{Наказ № 24}

30 квітня 1919 p.

Секретарь делєгації Петро Дідушок і член політичної секції делєгації Борис Матюшенко виїхали 3 мойого доручення - дня 24 квітня с.р. в Амстердам на міжнародню соціалістичну конференцію25.

Презідент делєгації: Г. Сидоренко

Секретарь: Петро Дідушок

\section{Наказ № 25}

1 мая 1919 p.

Призначаються Др. Кирило Білик attache à la delegation i ceнатор Джеймс Гаміль радником делегації оба $з$ днем 1. мая с.р. 3 місячним окладом по 4.000 франків кожному.

Презідент делєгації: Г. Сидоренко

Секретарь: Петро Дідушок

\section{Наказ № 26}

[Без дати]

Член політичної секції делєгації Др. Сергій Зархі командірований мною в Лондон по справам делєгації виїхав з 2. мая с.p.

Презідент делєгації: Г. Сидоренко

Секретарь: Петро Дідушок 


\section{Наказ № 27}

від 4 мая 1919 р.

Віце-президент делєації Др. Василь Панейко повернув 3 Швейцарії 3 с.м. і приступив до виконування своїх обов[']язків.

Презідент делєгації: Г. Сидоренко

Секретарь: Петро Дідушок

\section{Наказ № 28}

від 5 мая 1919.

${ }^{26}$ Томашівський Степан Теодорович (1875-1930) - український історик, публіцист і політик. Дійсний член НТШ (з 1899), його голова у 19131915 рр. Автор праць з історії української державності. Організатор Українського національного комітету в Парижі у 1919 р. 3 лютого 1919 р. - член дипломатичної місії УНР в Швейцарії, а відтак радник делегації УНР на Паризькій мирній конференції. 3 початку 1920 р. - член делегації ЗУНР на тій же конференції, а 3 червня - виконувач обов'язків iï голови. 31920 р. - голова дипломатичної місії ЗУНР в Лондоні. 14 травня 1920 р. у порозумінні з $\mathrm{C}$. Петрушевичем подав головам союзних держав меморіал про потребу утворення нейтральної незалежної західноукраїнської держави - Галицької Республіки (Східна Галичина, Західна Волинь, Холмщина, Підляшшя, Надсяння, Закарпатська Русь $\mathrm{i}$ Лемківщина).
Запрошений радником делєгації Др. Степан Томашівський ${ }^{26}$ прибув 4. с.м. і приступив до виконування своїх обов[']язків - 3 місячним окладом 5.000 фр[анків].

Презідент делєгації: Г. Сидоренко

Секретарь: Петро Дідушок

\section{Наказ № 29}

6 мая $1919 p$.

Член дипльоматичної секції п. Арнольд Марголін ${ }^{27}$, командірований мною в Лондон по справам делєгації виїхав сьогоднішнього дня.

Президент делєгації: Г. Сидоренко

Секретарь: Петро Дідушок

\section{Наказ № 30}

від 8 мая 1919 р.

Секретарь делєгації Петро Дідушок і член політичної секції Борис Матюшенко повернули з Амстердаму і приступили до виконування своїх обов[']язків, з сьогоднішним днем.

Президент делєгації: Г. Сидоренко

Секретарь: Петро Дідушок

${ }^{27}$ Марголін Арнольд Давидович (1877-1956) - український громадський і політичний діяч, юрист, дипломат, член УПСФ.

3 березня 1918 р. - член Генерального суду УНР та Української Держави. За Директорії - заступник міністра закордонних справ у кабінетах В. Чехівського і С. Остапенка. Представляв УНР під час переговорів 3 представниками Антанти в Одесі (1919 р.). У 1919-1920 рр. у складі дипломатичної делегації УНР брав участь у роботі Паризької мирної конференції, потім до листопада 1920 р. очолював українську місію в Лондоні. Від 1922 р. - на еміграції в США. 
28 Лозинський Михайло Михайлович (1880-1937) - український політичний діяч, дипломат, публіцист, перекладач, правознавець, професор (1921). Обраний до Української Національної Ради ЗУНР, у лютому1919 р. як член делегації брав участь у переговорах 3 місією Антанти, очоленою французьким генералом Бертелемі, а також у діяльності української делегації на Паризькій мирній конференції 1919-1920 рр. Від березня 1919 р. працював заступником державного секретаря (міністра) закордонних справ Західної області УНР.

${ }^{29}$ Вітовський Дмитро Дмитрович (1887-1919) - український політичний і військовий діяч, сотник Легіону Січових Стрільців, полковник, начальний командант УГА, Державний секретар військових справ ЗУНР. Член української делегації на Паризькій мирній конференції 1919-1920 pp.

${ }^{30}$ Кульчицький Олександр член делегації УНР на Мирну конференцію в Парижі (квітень - грудень 1919).

\section{Наказ № 31}

$$
9 \text { мая } 1919 \text { p. }
$$

Уповноважені державним секретаріатом західної области Укр[аїнської] Нар[одної] Респ[убліки], по справам заключення україно-польського перемир[']я п. Др. Михайло Лозинський ${ }^{28}$ i полковн[ик] Дмитро Вітовський ${ }^{29}$ з секретарем Кульчицьким ${ }^{30}$ прибули в Париж 8.с.м. і приступили до виконування своїх обов['] язків.

Президент делєгації: Г. Сидоренко

Секретарь: Петро Дідушок

\section{Наказ № 32}

$$
14 \text { мая } 1919 p \text {. }
$$

Аташе в делєгації п. Осип Мегас згідно своїй заяві вийшов 3 склада делєгації з 1. мая 1919 p.

Президент делєгації: Г. Сидоренко

Секретарь: Петро Дідушок

\section{Наказ № 33}

15 мая $1919 \mathrm{p}$.

Член дипльоматичної місії п. Арнольд Марголін повернувся 3 Лондону 14. мая с.p. і приступив до виконання своїх обов[']язків.

Президент делєгації: Г. Сидоренко

Секретарь: Петро Дідушок

\section{Наказ № 34}

[Без дати]

Член політичної секції Др. Зархі Сергій повернувся з Лондону 17 мая с.p. і приступив до виконування своїх обов[']язків.

Париж 17. мая 1919 р.

Президент делєгації: Г. Сидоренко

Секретарь: П. Дідушок

\section{Наказ № 35}

1 червня $1919 p$.

Членам комісії по заключенні українсько-польського перемир[']я Др. Михайлу Лозинському і полковнику Дмитру Вітовському призначається місячна платня по 5000 фр[анків], а секретарю комісії Олександру Кульчицькому 3000 фр[анків] з 1 червня $1919 \mathrm{p}$.

Президент делєгації: Г .Сидоренко

Секретарь: Петро Дідушок 


\section{Наказ № 36}

2 червня $1919 p$.

Другий секретарь Делєгації Антін Петрушевич повернувся 3 командіровки 2. с.м. і приступив до виконування своїх обов[']язків.

Президент делєгації: Г. Сидоренко

Секретарь: Петро Дідушок

Наказ № 37

3 червня $1919 p$.

II. секретарю делєгації Антону Петрушевичу призначається місячна платня в 4000 фр[анків] з 1. травня с.p. i III. Секретарю делегації Д[окто]ру Михайлу Рудницькому 4000 фр[анків] з 1 червня c.p.

Президент делегації Г. Сидоренко

Секретарь: П. Дідушок

\section{Наказ № 38}

28 червня $1919 p$.

${ }^{31}$ Галіп Артем (1887-?) - український політичний та державний діяч, дипломат, один 3 керівників Союзу Українських Громадян у Франції, радник делегації УНР на Мирній конференції в Парижі (квітень - грудень 1919), голова «Le comité de l'action» в Парижі (грудень 1919 - серпень 1920).
28 червня $1919 p$.

П. Джеймс Гаміль, представник американських Українців, приділений до делєгації, виїхав сегодня в Америку, і тим самим закінчив свою діяльність в делєгації.

Президент делєгації: Г. Сидоренко

Секретар: Антін Петрушевич

Наказ № 40

30 червня $1919 p$.

П. Арнольд Марголін, член дипльоматичної секції, виїхав сегодня на відпуск.

Президент делєгації: Г. Сидоренко

Секретар: Антін Петрушевич

\section{Наказ № 41}

30 червня $1919 p$.

П. Степан Томашівський, радник делєгації, приїхав нині 3 службової поїздки до Відня, в Париж, і приступив до виконування своїх обов[']язків.

Президент делєгації: Г. Сидоренко

Секретар: Антін Петрушевич 


\section{Наказ № 42}

30-ого червня 1919 .

Призначеного наказом від 5-ого травня с.р. за № 28 радником делєгації з 4-ого травня, п. Д[окто]р[а] Степана Томашівського, числити згідно з наказом міністра закордонних справ від 28-ого червня, № 54. радником делєгації з днем 1-ого марта с.р.

Президент делєгації: Г. Сидоренко

Секретар: Антін Петрушевич

\section{Наказ № 43}

1-ого липня 1919 p.

П. Борис Матюшенко, член політичної секції і Петро Дідушок, секретар делєгації, виїхали сегодня по дорученню президента делєгації в Швейцарію, для налагодження урядових справ.

Президент делєгації: Г. Сидоренко

Секретар: Антін Петрушевич

\section{Наказ № 44}

4-ого липня 1919 p.

Пану Карлові Дібрей, перекладчикові делєгації, призначає ся місячна платня фр[анків]1000. - з днем 1-ого липня с.p.

Президент делєгації: Г. Сидоренко

Секретар: Антін Петрушевич

\section{Наказ № 45}

4-ого липня 1919 p.

Платня, призначена наказом № 35. $з$ 1-ого червня с.р. пп. Лозинському, Вітовському і Кульчицькому, числить ся від дня їх приїзду в Париж, себто від 8-ого мая 1919 р.

Президент делєгації: Г .Сидоренко

Секретар: Антін Петрушевич

\section{Наказ № 46}

15-ого липня 1919 p.

П. Пилипу Чертопруду, швейцару, призначається місячна платня шістсот франків (fr.-600), а п. Ані Чертопруд чотириста франків (fr.-400) 3 дня 1-ого липня.

Президент делєгації: Г. Сидоренко

Секретар: Антін Петрушевич

\section{Наказ № 47}

15-ого липня 1919 p.

П. Олександр Шульгин член дипломатичної секції виїхав 11-ого с.м. на відпустку.

Президент делєгації: Г. Сидоренко

Секретар: Антін Петрушевич 


\section{Наказ № 48}

15-ого липня 1919 p.

П. полковник Дмитро Вітовський виїхав дня 7-ого с.м. по дорученню Голови делєгації як дипломатичний курієр на Україну.

Президент делєгації: Г. Сидоренко

Секретар: Антін Петрушевич

\section{Наказ № 49}

з 20-ого липня 1919 p.

П[ан]ні Маргареті Фуаць, писарцї делегації, призначається 3 днем 1-ого липня с.p. місячна платня чотириста франків.

Президент делєгації: Г. Сидоренко

Секретар: Антін Петрушевич

\section{Наказ № 50}

з 29-ого липня 1919 p.

Панї Ірі Женевієв, писарцї делег[ації] призначається на місяць серпень с.р. платня триста сімдесят п’ять франків.

Президент делєгації: Г. Сидоренко

Секретар: Антін Петрушевич

\section{Наказ № 51}

31 -ого серпня 1919 p.

П. Ісаєвич Дм[итро], член політ[ичної] секції делег[ації], ви-

32 Йдеться про конференцію Другого (Соціалістичного або Робочого) інтернаціоналу, що відбулася 1-9 серпня 1919 р. у м. Люцерн (Швейцарія). їхав сегодня до Швейцарії, щоби взяти участь в Соціалістичній Конференції в Люцерні ${ }^{32}$.

Президент делеєг[ації]: Г .Сидоренко

Секретар: Антін Петрушевич

\section{Наказ № 52}

з 1-ого серпня 1919 p.

П. Шульгин Олекс[андр], член диплом[атичної] секції, повернув сегодня з відпустки і приступив до виконування своїх обов['] язків.

Президент делєг[ації]: Г. Сидоренко

Секретар: Антін Петрушевич

Наказ № 53

з 4-ого серпня 1919 p.

П. Панейко Василь, товариш голови делєг[ації], виїхав сегодня на Україну.

Президент делєг[ації]: Г. Сидоренко

Секретар: Антін Петрушевич 


\section{Наказ № 54}

з 4-ого серпня 1919 р.

П[ан]на Пєрільо Олена, писарка делегації, розпочала 1-ого с.м. відпустку до дня 1-ого вересня с.р. 3 окладом півмісячним в сумі франків сто.

Президент делєг[аціi]: Г. Сидоренко

Секретар: Антін Петрушевич

\section{Наказ № 55}

33 Тишкевич Михайло (1857-1930) - український громадський і політичний діяч, дипломат, меценат, граф. 26 січня 1919 р. Директорією УНР призначений головою Надзвичайної дипломатичної місії УНР у Ватикані. 16 липня 1919 р. очолив делегацію УНР на Паризькій мирній конференції та дипломатичну місію УНР у Франції. 3 осені 1920 р. відійшов від політичної діяльності, оселившись у Польщі, в маєтку свого сина. Помер у м. Гнєзно (нині - Великопольського воєводства Республіки Польща).

${ }^{34}$ Цитович Борис (1889- ?) український і російський громадсько-політичний діяч. Служив чиновником у МВС УНР часів Директорії (ймовірно і Гетьманату). На запрошення керівника делегації УНР на Паризьку Мирну конференцію графа М. Тишкевича став іiі третім секретарем.

${ }^{35}$ Фернан Мазад (Fernand Mazade) (1861/1863-1939) французький поет, критик, журналіст, вчений. Співзасновник Французького Товариства Українознавства. Перекладач віршів Т. Г. Шевченка (1920), М. Т. Рильського. Допомагав Українській делегації на Паризькій мирній конференції 1919-1920 pp.

${ }^{36}$ Моцарский Валер'ян - секретар делегації УНР в Парижі (вересень 1919 - листопад 1920), секретар делегації УНР у Спа (липень 1920).
П. Михайло гр[аф] Тишкевич ${ }^{33}$ прибув до Парижа і дня 22-ого серпня приступив до виконування обов[']язків голови делєгації. П. Григорій Сидоренко виїхав дня 6-ого вересня на Україну.

Париж, 7-ого вересня 1919.

Президент делєгації: Тишкевич

Секретар делєгації: Антін Петрушевич

\section{Наказ № 56}

Пп. Арнольд Марголін, член дипломат[ичної]секції, згідно своїй заяві з 28-ого серпня, і Олександр Шульгин, член дипломат[ичної] секції, згідно своїй заяві з 7-ого вересня виступили 3 делєгації і виїхали з Парижу.

Париж, 9-ого вересня 1919.

Президент делєгації: Тишкевич

Секретар делєгації: Антін Петрушевич

\section{Наказ № 57}

П. Борис Цитович ${ }^{34}$ призначується 3 днем 15 -ого вересня помічним секретаром делєгації з місячною платнею трьох тисячів (3000.-) франків.

Париж, 20-ого вересня 1919.

Президент делєгації: Тишкевич

Секретар делєгації: Антін Петрушевич

\section{Наказ № 58}

П[а]н Фердинанд Мазад ${ }^{35}$ призначує ся 3 днем 1-ого вересня перекладчиком делєгації з місячною платнею франків шістьсот (fr. 600.-).

Париж, 20-ого вересня 1919.

Президент делєгації: Тишкевич

Секретар делєгації: Антін Петрушевич

\section{Наказ № 59}

Пан Моцарський ${ }^{36}$ призначується 3 днем 1-ого жовтня особистим прибічником п[ана]президента делєгації, 3 місячною платнею - тисячу - франків (fr.1000. -).

Париж, 30-ого вересня 1919.

Справлено «тисячу»

АП (підпис)

Президент делєгації: Тишкевич

Секретар делєгації: Антін Петрушевич 
${ }^{37}$ Пол Гроот (Paul de Groote) посол Королівства Бельгія у Швейцарії.
${ }^{38}$ Шумицький Микола (18891981) - український громадсько-політичний діяч, архітектор та дипломат. Полковник Армії УНР. 5 вересня 1919 р. його призначено членом української делегації на Паризьку мирну конференцію, а від вересня 1920 р. він увійшов до складу Української Дипломатичної Місії у Франції як радник з економічних питань. З 1921 р. призначений послом в Аргентині. В 1924 р. М. Шумицький відійшов від дипломатичної роботи.

${ }^{39}$ Галяфре Леонід - секретар делегації УНР на Мирну конференцію в Парижі (вересень 1919 - листопад 1920), член місії УНР у Парижі (березень 1921 - серпень 1922)

\footnotetext{
40 Далі текст нерозбірливий через пошкодження.
}

\section{Наказ № 60}

Пан бар[он] Гроот ${ }^{37}$ призначується 3 днем 11. вересня 1919. фаховим урядовцем делєгації, а іменно експертом для фінансових справ, з окладом три тисячі франків платні і дві тисячі на екстренні видатки в місяць.

Париж, 30. вересня 1919.

Президент делєгації: Тишкевич

Секретар делєгації: Антін Петрушевич

\section{Наказ № 61}

Пан Микола Шумицький ${ }^{38}$ зачисляється 3 днем 1-ого падолиста 1919 р. тимчасово радником делєгації.

Париж, 1 падолиста 1919.

Президент делєгації: Тишкевич

Секретар: Антін Петрушевич

\section{Наказ № 62}

П[а]ну Карлу Дібрею призначується 3 днем 1-ого падолиста 1919 р. місячна платня фр[анків] дві тисячі (fr.2000. -).

Париж,1 падолиста 1919.

Президент делєгації: Тишкевич

Секретар: Антін Петрушевич

\section{Наказ № 63}

Пан Лєонід Галяфре ${ }^{39}$ призначається 3 днем 20 серпня 1919 р. урядовцем Укр[аїнської] Делєгації в Парижі з місячною платнею фр[анків] дві тисячі (2000).

Париж, 5 падолиста 1919.

Президент делєгації: Тишкевич

Секретар: Михайло Рудницький

\section{Наказ по Делегації № 64}

з дня 24-ого падолиста 1919

Секретар Делєгації п. Дїдушок відкомандїрує[ть]ся у розпорядженя Мінїстерства закордонних справ.

Радник Делєгації п. Шелухин призначує[ть]ся виконуючим нагляд над концелярією Делєгації.

Доводи[ть]ся до відома усїх членів Делєгації, що праця у Делєгації проводиться від 10-12 та від 3-6 г.

Всїм членам Делєгації пропоную подїлитись між собою дижурством згідно службових часів.

Прийом у Президента Делегації відбуває[ть $]$ ся ........ ${ }^{40}$.

Президент делєгації: Тишкевич

Секретар: Михайло Рудницький 


\section{Наказ по Делегації № 65}

з дня 28-ого падолиста 1919

${ }^{41}$ Текст нерозбірливий через пошкодження.
42 Комісія генерала Боти:

2 квітня 1919 р. за дорученням керівників Паризької мирної конференції розпочала свою роботу комісія бурського генерала Боти (Люїс) щодо припинення війни між Польщею та ЗУНР. Зокрема, комісія наказала обмежити армії обох країн до 20 тис. вояків і встановила нову демаркаційну «лінію Боти». $[\ldots]^{41}$

\section{Наказ № 66}

з дня 17 грудня 1919.

Згідно $з$ складеною заявою Д[окто]ром В. Панейком в імени уповноважених Державним Галицьким Секретаріятом членів Делєгації, з нинішним днем перестають бути членами Делєгації і звільняються від виконування своїх обов[']язків:

1) Д[окто]р В.Панейко,

2) Д[окто]р. Ст. Томашівський,

3) Антін Петрушевич,

4) Олександер Кульчицький.

Президент Делєгації: Тишкевич

Секретар: Михайло Рудницький

\section{Наказ № 67}

з дня 17 грудня 1919.

Згідно з присланою заявою Шефа Західно-Української Республіки Д[окто]ра Євгена Петрушевича 3 дня 12 грудня: - що мандат уділений свого часу Д[окто]рові Михайлови Лозинському відносився тільки до справи перемир[']я та, що з розв[']язанням Комісії генерала Боти ${ }^{42}$ сей мандат вгас - Д[окто]p Михайло Лозинський перед з нинішним днем буде членом Делєгації.

Президент Делєгації: Тишкевич

Секретар: Михайло Рудницький

\section{Наказ № 68}

з дня 17 грудня 1919.

Згідно з складеною заявою Д[окто]ром Кирилом Біликом з дня 17 грудня - він перестає з нинішним днем бути членом Делєгації.

Президент Делєгації: Тишкевич

Секретар: Михайло Рудницький

\section{Наказ № 69}

з дня 30 грудня 1919.

Згідно з одержаною мною телєграмою від Уряду з дня 18. грудня яка була прочитана на засіданні 26-го грудня с.p. і (якої текст $\epsilon$ поданий тут нище) оголошую Делєгацію в теперішньому складі зліквідованою з днем 26-го цього грудня. Мною буде сформована нова Делєгація з членами по мойому вибору. Тому доручається Секретаріятові підготовити матеріял для ліквідації і повідомити всіх членів Делєгації, що повинні здати грошеві відчити, як що в них залишаються казенні гроші - передати їх, передати дипльоматичні пашпорти та уповноваження а також відомости, з якого часу вони знаходяться на державній службі в У[країнської] Н[ародної] Р[еспублікої] задля одержання ліквідаційних грошей. 
Президент Делєгації: Тишкевич

Секретар: Михайло Рудницький

Копія телєграми від Уряду з дня 18 грудня є слідуюча:

Abschriff 24/12

$\begin{array}{lllll}\text { Varsovie } 421 & 101 / 0 & 18 & 14 & 40\end{array}$

Selon ordre Président du Directoire Gouvernement vot mo vous changer personnel de votre million d'après votre avis personnel ayant le droit renvoyer membres de mission sans différence de rangs et nommer les nouveaux selon votre choix. Droit représentation Paris de République Ukrainienne appartient exclusivement vous chef de mission pleins pouvoirs d'autres délégués annulés proposons vous prendre tout argent de mission sans exceptation et le dépenser personnellement selon votre avis ...

Président Conseil Ministres. André Livitzky Secrétaire d'Etat

Khrystuk.

\section{Наказ № 70}

з дня 30 грудня 1919 р.

Членами нової Делєгації призначаються від 27 грудня с.р. слідуючі члени дотеперішньої Делєгації:

1) Володимир Колосовський, радник у військ[ових] справах 3 платнею п’ять тисяч франків місячно;

2) Д[окто]p Михайло Рудницький, секретар з плат[нею] п’ять тисяч фр[анків ] міс[ячно];

3) Хведір Савченко, attache' з плат[нею] чотири тисячі фр[анків ] міс[ячно];

4) Лєонід Галяфре, другий секретар 3 плат[нею] тритисячі фр[анків ] міс[ячно];

5) Валеріян Моцарський, особистий секретар Голови Делєгації з платнею дві тисячі фр[анків] місячно.

Президент Делєгації: Тишкевич

Секретар: Михайло Рудницький

\section{Наказ № 71}

з дня 30 грудня 1919 p.

На посаду урядовця Секретаріяту - регістраторки призначується п[ан]на Марсель Вевер, з платнею чотирохсот франків місячно.

Президент Делєгації: Тишкевич

Секретар: Михайло Рудницький

\section{Наказ № 72}

з дня 30 грудня 1919 p.

Пан бар[он] де Грот експерт для фінансових справ перестає бути 3 днем 11 грудня урядовцем Делєгації.

Президент Делєгації: Тишкевич

Секретар: Михайло Рудницький 


\section{Наказ № 73}

з дня 30 грудня 1919 р.

Пану Фернанду Мазаду підвищується місячна платня з днем 1-го 1920 р. на тисячу франків.

Президент Делєгації: Тишкевич

Секретар: Михайло Рудницький

\section{Наказ № 74}

з дня 1 січня 1920 p.

43 Лучинський Микола - перекладач, член делегації УНР на Мирну конференцію в Парижі (квітень-вересень 1919), секретар місії УНР у Ватикані (вересень-листопад 1919).
44 Товариство «Украіліян» українське кооперативне товариство у Франції.
45 Др. Барчак, Борщак Ілля (справжнє Баршак, підписувався Ілько Боршзак) (1892-1959) український історик, публіцист і літературознавець.

${ }^{46}$ Йдеться про конференцію засідання Верховної ради держав Антанти і держав, що до них приєдналися. Конференція проходила 19-26 квітня 1920 р. у м. Сан-Ремо (Італія). В ній брали участь прем>єр-міністр Великої Британії Д. Ллойд Джордж і міністр закордонних справ лорд Дж. Керзон, прем'єр-міністр Франції О. Мільєран, прем'єр-міністр Італії Ф. Нитті. Японія була представлена послом К. Мацуї. Американський представник - посол в Римі Джонсон прибув на конференцію як спостерігач. Вони брали участь в обговоренні питань щодо Греції та Бельгії. з дня 21 січня 1920 р.

Оцим призначується Комісія для перевірення рахунків тов[ариства] «Украіліян» ${ }^{44}$ по проханню п. В. Тимошенка, -3 п. Вол. Колосовського і М.Лучинського.

Президент Делєгації: Тишкевич

Секретар: Михайло Рудницький

\section{Наказ № 76}

з дня 1 лютого 1920 p.

Оцим призначується п. Микола Шумицький, був[ший] член Делєгації - радником Делєгації з дня 1 лютого 1920 р. -

Підстава: заява п. Миколи Шумицького з дня...

Президент Делєгації: Тишкевич

Секретар: Михайло Рудницький

\section{Наказ № 77}

з дня 1 марта 1920 p.

Оцим призначується п. Д[окто]р Ілля Барчак ${ }^{45},-6[$ бвший $]$ атташе Американської Делєгації - помічником секретаря Делєгації 3 місячною платою два тисячі (2000) франків.

Президент Делєгації: Тишкевич

Секретар: Михайло Рудницький

\section{Наказ № 78}

з дня 14 квітня 1920 р.

$\S 1$

16 цього місяця я виіздю на конгресс у Сен Ремо ${ }^{46}$. Під час моєї відсутності керування біжучими справами Делєгації покладаю на Першого Секретаря Д[окто]ра Рудницького, котрому пропонується ден[ну] Службову Корреспонденцію пересилати на Сен Ремо. Разом зі мною виїзжають: Радник Делєгації Микола Шумицький, 
47 alles et restour (фр.) - туди й назад.

\footnotetext{
${ }^{48}$ Адамович Петро - військовий аташе (жовтень1919 листопад 1920).
}

Другий Секретар Лсонід Галафре і мій особистий Секретар Валеріан Моцарський.

$\S 2$

Подорож до Сен Ремо на конгрес рахується, як службова командировка і тому кожному з командируємих виплачуються наперед за два тижня добові гроші по $50 \mathrm{fr}$. fr. денно за весь час подорожі, рахуючи першим днем 16 квітня ц/p., а також виплачуються гроші квіток 1 ої кляси по залізниці до Сен Ремо (alles et restour) ${ }^{47}$.

Президент Делєгації: Тишкевич

Секретар: Михайло Рудницький

$\S 3$

Всі важнійші рішення в біжучих справах Делєгації повинні бути прийняті Секретарем в згоді з радниками Делєгації пп. Колосовським і Савченком а по повороті Голови затверджені ним.

Президент Делєгації: Тишкевич

Секретар: Михайло Рудницький

\section{Наказ № 79}

дня 13 мая 1920 .

Нинішнього дня я повернувся 3 Сан-Ремо 3 секретарями: п. Л. Галяфре та В. Моцарським і вступив у виконування своїх обов[']язків. Секретарю Делєгації п. Мих[айлу] Рудницькому доручаю вернутись до своїх обов[']язків.

Президент Делєгації: Тишкевич

\section{Наказ № 80}

дня 18 мая 1920 .

Наказую, щоб з 20. ц.м. урядові години Делєгації були з 9 год[ини ] ранку до 2-ої г[одини] без перерви, - а це на час літніх місяців.

Президент Делєгації: Тишкевич

Секретар: Михайло Рудницький

\section{Наказ № 81}

дня 20 мая 1920 .

Відряджений до Української Делєгації в Парижі д[ня] 9. січня 1919 р. і пробуваючий в мойому розпорядженню полковник Адамович ${ }^{48}$ призначується на посаду аташе Делєгації 3 місячною платнею чотири тисячі (4000) франків для виконування обов[']язків помішника військового агента.

Президент Делєгації: Тишкевич

Секретар: Михайло Рудницький

\section{Наказ № 82}

дня 25 мая 1920 .

3 огляду на скорочення «штатів» Делєгації згідно з розпорядження Уряду дн[я].... п. Микола Лучинський звільняється 3 обов[']язків помічника секретаря 3 днем 1 червня 1920 p.

Президент Делєгації: Тишкевич

Секретар: Михайло Рудницький 


\section{Наказ № 83}

дня 25 мая 1920 p.

Пропоную 2-ому Секретарю: п. Лєоніду Галяфре прийняти всі грошові справи і Касу від виконуюч[ого] обов[']язки скарбника Делєгації Д[окто]ра М. Рудницького і про прийняття скласти мені рапорт разом до справозданням стану каси.

Президент Делєгації: Тишкевич

Секретар: Михайло Рудницький

\section{Наказ № 84}

дня 1 червня $1920 \mathrm{p}$.

31 (першого) червня 1920 р. підвищую платню Другому Секретарю Делєгації і вик[онуючому] об[обв'язки] скарбника Лєоніду Галяфре, поміщнику Секретаря Ілії Борщаку і мому особистому секретарю Валеріану Моцарському а власне:

п. Лєоніду Галяфре 4000 ф[ранків] місячно,

п. Ілії Борщаку 3000 місячно,

п. Валеріану Моцарському 4000 місячно.

Платня підвищується згідно тому, як одержували іï їх попередники.

Президент Делєгації: Тишкевич

Секретар: Михайло Рудницький

\section{Наказ № 85}

дня 10 червня 1920 .

Вважаючи, що помешкання займаемое Делегації (37, rue la Perouse) обходиться дуже дорого (4.000 фр[анків]місяць), а з другого боку не маючи можливости в сучасний мент знайти підходяще помешкання, котре для потреб Делєгацій могло би бути значно меньше, а також не бажаючи витрачати з сум на представництво (зараз не істнуючих) на осібне помешкання з салоном, як це було досі, -------- я 12 цього червня переізжаю до помешкання, яке займає Делєгація. Також пропоную переіхати до Делєгації: вик[онуючому] обов[']язки скарб[ника] Делєгації Леоніду Галяфре і мойому особистому Секретарю Валеріану Моцарському, котрим по своїм обов[']язкам бажаю бути завше можливо ближче до Делєгаціï.

Вик[онуючому] обов[']язки скарбника Делєгації п. Галяфре при розрахунках за помешкання наказую керуватись слідуючим:

За свій покій (спальний) я буду доплачивать денно 20 фр[анків].

Пану Галяфре вносити місячно 200 фр[анків],

пану Моцарському вносити місячно 110 фр[анків] при чім його кімната буде вживаться в урядові годині як кімната належна до канцелярії.

Президент Делєгації: Тишкевич

Секретар: Михайло Рудницький 


\section{Наказ № 86}

з дня 22 червня 1920 p.

Згідно з проханням радника Делєгації п. Хв. Савченка дати йому місячної відпуски для поправки здоровля згоджуюсь - і прошу рахувати цей відпуск з нинішнього дня.

Президент Делєгації: Тишкевич

Секретар: Михайло Рудницький

\section{Наказ № 87}

з дня 1 липня 1920 p.

${ }^{49}$ Конференція в Спа - збори представників Антанти за участі Польщі, Чехословаччини та Німеччини, що проходили 5-16 липня 1920 р. в м. Спа (Бельгія).
${ }^{50}$ Саєнко Аристарх - урядовець Українського Пресового Бюро в Парижі, урядовець Делегації на Паризькій мирній конференції з 23 липня 1920 р. з дня 1 липня 1920 p.

Позаяк подорож на Конференцію в Спа є урядовою подорожжю, - тому згідно з законом призначується Голові Делєгації і його секретарю за весь час пробування в Спа п’ятдесят (50) франків добових.

Президент Делєгації: Тишкевич

Секретар: Михайло Рудницький

\section{Наказ № 89}

з дня 18 липня 1920 p.

Нині вернувся я 3 моїм особистим секретарем п. В. Моцарським з Конференції Спа в Париж.

Президент Делєгації: Тишкевич

Секретар: Михайло Рудницький

\section{Наказ № 90}

3 дня 23 липня 1920 p.

Перший секретар Мих[айло]Рудницький і 2-ий секретар Лєонід Галяфре рапортами з дня 18 червня донесли, що перший передав, а другий прийняв ведення грошової справи Делєгації. В мент передачі в делєгаційній касі скарбника знаходилось готівкою 1795 фр[анків] тисяч сімсот дев'яносто п'ять франків і 85 сантімів.

Президент Делєгації: Тишкевич

Секретар: Михайло Рудницький

\section{Наказ № 91}

з дня 23 липня 1920 p.

Пан Аристарх Саєнко ${ }^{50}$ бувший урядовець Укр[аїнського] Пресового Бюра призначується урядовцем Делєгації з платнею шістьсот франків місячно, з 15 липня ц.р.

Президент Делєгації: Тишкевич

Секретар: Михайло Рудницький 


\section{Наказ № 92}

з дня 29липня 1920 p.

3 огляду на скорочення «штатів» Делєгації згідно з розпорядженням Уряду і брак коштів п. Михайло Рудницький звільняється $з$ обов[']язків Першого Секретаря Делєгації $з$ днем 1-го серпня $1920 \mathrm{p}$.

Президент Делєгації: Тишкевич

\section{Наказ № 93}

з дня 29 липня 1920 p.

3 огляду на скорочення «штатів» Делєгації згідно 3 розпорядженням Уряду і брак коштів п. Ілько Борщак звільняється 3 обов[']язків Пом[ічника] Секретаря Делєгації з днем 1-го серпня $1920 \mathrm{p}$.

Президент Делєгації: Тишкевич

\section{Наказ № 94}

з дня 1 серпня 1920 р.

Наказ по Делєгації ч. 92 д дня 29 липня 1920 р. відміняється (в справі звільнення Перш[ого] Секр[етаря] Д[окт]ра Рудницького).

Президент Делєгації: Тишкевич

\section{Наказ № 95}

16 серпня 1920 p.

$\S 1$

Наказом Високої Директорії з 20 липня 1920 р. граф Михайло Тишкевич звільнений з посади Голови Делєгації і на його місце призначається Колєгія, яка згідно наказу Високої Директорії передала тимчасове керування справами Делегації мені.

$\S 2$

Через відмовлення Графа Тишкевича здати справи Колєгії, сього числа приступить до переселення його в їхньому .......

$\S 3$

Всі накази і розпорядження Графа Тишкевича починаючи 3 22 липня с.р. вважаються не дійсними і виконанню не належать.

$\S 4$

Пану Секретареві Делєгації М.Рудницькому пропоную всі офіціяльні накази виходячи з Делєгації представляти мені на розгляд до розпорядження. Також ...

$\S 5$

Радник Делєгації п. Микола Шумицький на підставі наказу Директорії негайно .... Делегується в розпорядження Міністерства Закордонних Справ.

$\S 6$

Пан Аристарх Саєнко, бувший урядовець Укр[аїнського] Пресового Бюра призначується урядовцем Делєгації з платнею шістсот...франків місячно з 15 липня ц.р. 
$\S 7$

Всім Урядовцям лишатися на місцях до слідуючого розпорядження.

По уповноваженню Колєгії

Член Колєгії М. Лучинський

\section{Spytska Olena}

\section{ADMINISTRATIVE AND FINANCIAL ACTIVITY OF THE UKRAINIAN DELEGATION MANAGEMENT AT THE PARIS PEACE CONFERENCE 1919-1920 FROM THE PERSPECTIVE OF A NEW HISTORICAL SOURCE}

The article highlights some organizational activities which provided personnel and financial support for UPR delegation's work in the Paris Peace Conference 1919-1920. This work consisted of efforts to gain UPR's independence recognition by leading and others states of the world; to get them to take into consideration interests of the Ukrainian people, because of the postwar geopolitical changes in Central Europe; to cooperate in political, military, commercial and economic fields with other countries. It characterizes main directions of personnel part of this work - the dynamics in personnel changes, efforts to engage qualified specialists and technical workers, control over delegation members' business trips, financial expenses aimed at executing tasks, which were given to the delegation.

Key words: UPR, Paris, Conference, delegation, order. 